\title{
PENGARUH LOKASI DAN PROMOSI TERHADAP KEPUTUSAN PEMBELIAN PADA PRODUK MANSET SAFETY DI TOKO TAWAKAL PONDOK AREN - TANGERANG SELATAN
}

\author{
${ }^{1 *}$ Ela Hulasoh, ${ }^{2}$ Riki \\ Universitas Pamulang, Tangerang Selatan, Banten, Indonesia \\ *dosen01910@unpam.ac.id
}

\begin{abstract}
Abstrak
Tujuan dari penelitian ini adalah untuk mengetahui seberapa besar pengaruh lokasi terhadap keputusan pembelian pada produk Manset Safety di Toko Tawakkal Pondok Aren - Tangerang Selatan, untuk mengentahui seberapa besar pengaruh promosi terhadap keputusan pembelian pada produk Manset Safety di Toko Tawakkal Pondok Aren Tangerang Selatan, dan untuk mengetahui seberapa besar pengaruh lokasi dan promosi terhadap terhadap keputusan pembelian pada produk Manset Safety di Toko Tawakkal Pondok Aren - Tangerang Selatan. Metode yang digunakan adalah pendekatan asosiatif kuantitatif, digunakan accidental sampling dengan 89 responden sebagai sampel dari 776 populasi yang kemudian dianalisis pengaruhnya secara parsial dan simultan dengan menggunakan analisis regresi linier berganda, koefisien determinasi serta pengujian hipotesis dengan uji $t$ dan uji $f$ dan uji R2. Hasil penelitian variabel lokasi memiliki pengaruh yang signifikan terhadap keputusan pembelian, dimana diperoleh nilai thitung $>\mathrm{t}$ table $(2,608<1,988)$ dan sig $<0,05(0,011<0,05)$. Promosi memiliki pengaruh yang signifikan terhadap keputusan pembelian, dimana diperoleh nilai $\mathrm{t}$ hitung $>\mathrm{t}$ table $(2,382$ $<1,988)$ dan sig < 0,05 $(0,019>0,05)$. Lokasi dan promosi memiliki pengaruh yang signifikan secara silmultan terhadap keputusan pembelian, dimana diperoleh nilai $\mathrm{f}$ hitung $>\mathrm{f}$ table $(5,085<3,11)$ dan sig $>0,05(0,008>0,05$. Dapat disimpulkan bahwa terdapat pengaruh yang signifikan antara lokasi dan promosi terhadap keputusan pembelian.

Kata Kunci : Lokasi, Promosi, Keputusan Pembelian
\end{abstract}

\begin{abstract}
The purpose of this study was to determine how much influence location has on purchasing decisions for Safety Cufflinks at Tawakkal Stores Pondok Aren - South Tangerang, to find out how much influence promotion has on purchasing decisions for Safety Cufflinks at Tawakkal Stores Pondok Aren - South Tangerang, and to find out how much influence location and promotion have on purchasing decisions on Safety Cuff products at Tawakkal Stores Pondok Aren - South Tangerang. The method used is a quantitative associative approach, accidental sampling is used with 89 respondents as a sample of 776 populations which is then analyzed for its effect partially and simultaneously using multiple linear regression analysis, coefficient of determination and hypothesis testing with $t$ test and f test and $R 2$ test. The results of the study of the location variable have a significant influence on purchasing decisions, where the value of $t$ count $>t$ table $(2,608<$ $1,988)$ and sig $<0.05(0.011<0.05)$. Promotion has a significant influence on purchasing decisions, where the value of $t$ count $>t$ table $(2.382<1.988)$ and sig $<0.05(0.019>0.05)$. Location and promotion have a simultaneously significant effect on purchasing decisions, where the value of $f$ count $>f$ table $(5.085<3.11)$ and sig $>0.05(0.008>0.05$. It can be concluded that there is a significant effect between location and promotion of purchasing decisions.
\end{abstract}

Keywords: Location, Promotion, Purchase Decision. 


\section{PENDAHULUAN}

Perkembangan bisnis dari dulu hingga saat ini disebabkan oleh perubahan pola pikir manusia yang dinamis. Dengan dasar inilah kegiatan pasar sangat dibutuhkan oleh organisasi maupun perusahaan sebagai ujung tombak bagi kehidupannya, baik itu organisasi atau perusaahaan yang mencari laba atau nirlaba. kegiatan pasar dimaksud diharapkan dapat mendukung tercapainya tujuan dan kelangsungan perusahaan itu sendiri. Dalam mencapai tujuan dan kelangsungan suatu usaha tidak luput dari persaingan produk-produk sejenis antar pelaku usaha. Maka kegiatan pemasaran adalah jantung dari kegiatan setiap usaha/bisnis. Dengan demikian, demi memenangkan persaingan dalam meraih pasar, berbagai upaya dilakukan oleh para pelaku usaha/bisnis, baik dari sisi pelayanan, meningkatkan kualitas produk hingga membuat strategi pemasaran salah satunya melalui promosi dan menentukan lokasi sebaik mungkin dalam upaya memenangkan persaingan dan meningkatkan jumlah pembelian produk atau jasa.

Toko Tawakkal yang berlokasi di Jl. Japos Raya, RT.04/03, Jurang Mangu Barat, Kec. Pondok Aren, Kota Tangerang Selatan yang menjual produk manset safety di bidang fashion. Berdasarkan observasi penulis pada toko tersebut, Nampak lokasi yang kurang strategis dan promosi yang kurang optimal berdampak pada penjualan yang belum maksimal yang ditandai dengan target pencapaian yang fluktuatif.

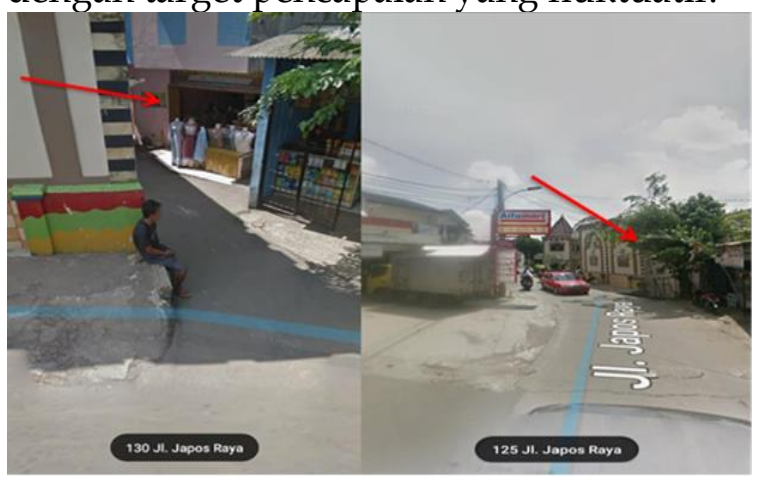

Sumber : Google Map (2019).

Gambar 1. Gambar Keadaan Toko Tawakkal
Promosi yang dilakukan oleh Toko Tawakkal masih terbilang minim, Toko Tawakkal hanya mengandalkan media sosial seperti instagram yang biaya promosinya sebesar Rp 200.000 per bulan dan tidak melakukan promosi yang lain seperti iklan, buy 1 get 1 ataupun melalui pemasaran langsung adapun atribut promosi seperti spanduk, banner, reklame yang yang ada masih kurang memadai terlihat pada gambar 1. Promosi yang kurang optimal akan mempengaruhi jumlah penjualan oleh karena itu berimbas pada target penjualan yang tidak tercapai. Sejalan dengan hal itu dapat dilihat pada gambar 2 di bawah ini.

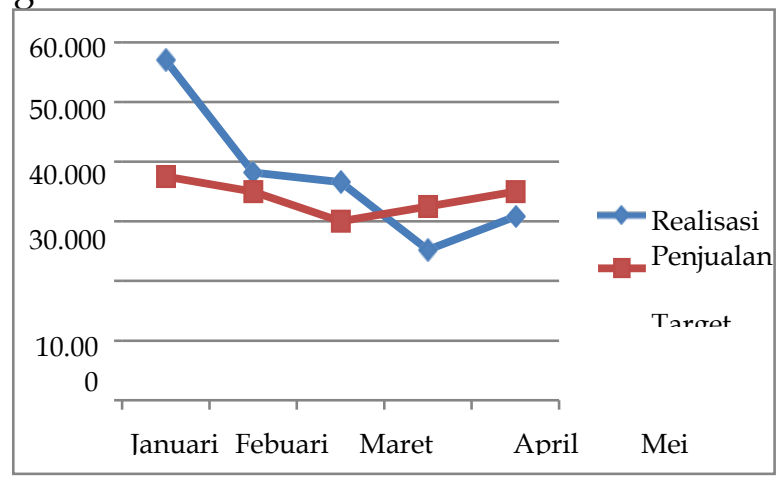

Sumber : Data Perusahaan (2019)

Gambar 2. Grafik Target Penjualan dan

Realisasi Penjualan Produk Manset Safety Desember 2018 - April 2019

\section{Rumusan Masalah}

Rumusan masalah dalam penelitian ini adalah sebagai berikut: seberapa besar pengaruh lokasi terhadap keputusan pembelian konsumen pada produk Manset Safety di Toko Tawakkal. Seberapa besar pengaruh Promosi terhadap keputusan pembelian konsumen pada produk Manset Safety di Toko Tawakkal?, seberapa besar pngaruh lokasi dan promosi terhadap keputusan pembelian konsumen pada produk Manset Safety di Toko Tawakkal?

Berdasarkan sejumlah uraian di atas, maka penelitian ini diangkat dengan judul: Pengaruh Lokasi Dan Promosi Terhadap Keputusan Pembelian Pada Produk Manset Safety Di Toko Tawakkal Pondok Aren - Tangerang Selatan. 


\section{TINJAUAN PUSTAKA}

\section{Lokasi}

Menurut Heizer \& Render (2015:78), lokasi adalah pendorong biaya dan pendapatan, maka lokasi seringkali memiliki kekuasaan untuk membuat strategi bisnis perusahaan. Sedangkan menurut Buchari Alma (2011:13) bahwa lokasi adalah tempat perusahaan beroperasi atau tempat perusahaan melakukan kegiatan untuk menghasilkan barang dan jasa yang mementingkan segi ekonominnya. Lain hanya menurut Lupiyoadi (2013:61) "lokasi berhubungan dengan tempat dimana perusahaan harus bermarkas dan melakukan operasi". Indikator yang mempengaruhi lokasi menurut Tjiptono (2014:346) diantaranya adalah :

a. Akses, misalnya lokasi yang dilalui atau mudah dijangkau sarana transformasi umum.

b. Visibilitas, yaitu lokasi atau tempat yang dapat dilihat dengan jelas dari jarak pandang normal.

c. Lalu lintas (traffic), menyangkut dua pertimbangan utama berikut: 1 ) Banyaknya orang-orang lalu lalang bisa memberikan peluang besar terhadap terjadinya impulse-buying, yaitu keputusan pembelian yang seringkali terjadinya spontan, tanpa perencanaan, dan atau tanpa melalui usaha-usaha khusus. 2) Kepadatan dan kemacetan lalu-lintas bisa pula menjadi hambatan.

d. Tempat parkir yang luas, nyaman, dan aman baik untuk kendaraan roda dua ataupun roda empat.

e. Ekspansi, yaitu tersedianya tempat yang cukup luas apabila ada perluasan dikemudian hari.

f. Lingkungan, yaitu daerah sekitar yang mendukung produk yang ditawarkan.

\section{Promosi}

Menurut Kotler dan Amstrong (2013:180), "Promotion means activities that commucate the merits of the product and persuade target customers to buy it", artinya promosi merupakan kegiatan yang mengkomunikasikan manfaat dari sebuah produk dan membujuk target konsumen untuk membeli produk tersebut. Menurut Rangkuti (2010:50), "Promosi adalah kegiatan penjualan dan pemasaran dalam rangka mengimformasikan dan mendorong permintaan terhadap produk, jasa, dan ide dari perusahaan dengan mempengaruhi konsumen agar mau membeli produk dan jasa yang dihasilkan oleh perusahaan". Dan menurut Kotler (2009:172) promosi adalah sarana dimana perusahaan berusaha menginformasikan, membujuk, dan mengingatkan konsumen secara langsung maupun tidak langsung tentang produk dan merek yang dijual. Promosi pun dapat dilakukan menggunakan metode online sebagaimana (Haryadi et al., 2021) mengatakan bahwa promosi yang dilakukan melalui online akan dapat mecakup keseluruhan masyarakat.

\section{Keputusan Pembelian}

Menurut Kotler dan Amstrong (2012:149) menyatakan bahwa keputusan pembelian adalah tahap proses keputusan dimana konsumen secara aktual melakukan pembelian produk. Dapat disimpulkan bahwa keputusan pembelian merupakan kegiatan pemecahan masalah yang dilakukan individu dalam pemilihan suatu barang atau jasa dari beberapa alternatif pilihan yang sedang dibutuhkan konsumen.

\section{METODE}

Jenis penelitian ini adalah Kuantitatif Asosiatif, di mana menurut Sugiyono (2016:11), penelitian asosiatif merupakan penelitian yang bertujuan untuk mengetahui pengaruh ataupun hubungan antara dua variabel atau lebih. Berlokasi di Toko Tawakkal, Pondok Aren, Tangerang Selatan. Dengan jumlah populasi sebesar 776 konsumen dan sampel sebesar 89. Adapun teknik samplingnya 
adalah incidental sampling yaitu berdasarkan responden yang berhasil di temui. Metode pengumpulan data dilakukan dengan observasi, kuisioner, studi pustaka dan dokumentasi, sedangkan uji instrument dilakukan dengan uji validitas, uji reliabilitas dan uji asumsi klasik. Adapun teknik analisis data dilakukan dengan uji regresi linier berganda, koefisien determinasi, uji hipotesis dengan menggunakan uji t dan uji F.

\section{HASIL DAN PEMBAHASAN}

Table 1. Hasil Uji Regresi Linier Berganda

\begin{tabular}{|c|c|c|c|c|c|c|}
\hline \multicolumn{7}{|c|}{ Coefficients $^{\mathrm{a}}$} \\
\hline \multirow{2}{*}{\multicolumn{2}{|c|}{ Model }} & \multicolumn{2}{|c|}{$\begin{array}{l}\text { Unstandardized } \\
\text { Coefficients }\end{array}$} & \multirow{2}{*}{$\begin{array}{c}\text { Standardized } \\
\text { Coefficients }\end{array}$} & \multirow[t]{2}{*}{$t$} & \multirow[t]{2}{*}{ Sig. } \\
\hline & & $\mathrm{B}$ & Std. Error & & & \\
\hline \multirow[t]{3}{*}{1} & (Constant) & 26.046 & & & 4.748 & .000 \\
\hline & Lokasi_Total & .200 & .097 & .219 & 2.070 & .041 \\
\hline & Promosi_Total & .204 & .114 & .189 & 1.788 & .077 \\
\hline
\end{tabular}

Berdasarkan tabel di atas diperoleh persamaan regresi berganda sebagai berikut $: Y=26,046+0,200 X 1+0,204 X 2$. Persamaan regresi tersebut mempunyai makna sebagai berikut :

a. Yang artinya konsumen akan tetap membeli produk tersebut meskipun lokasi dan promosi yang diberikan masih kurang, karena pada dasarnya konsumen membutuhkan produk tersebut untuk memenuhi kebutuhanya.

b. Variabel lokasi (X1) berpengaruh positif terhadap keputusan pembelian $(Y)$ dengan nilai koefisien sebesar 0,200.

Table 2. Hasil Uji Koefisien Determinasi X1 dan X2 Terhadap Y

\begin{tabular}{|c|c|c|c|c|}
\hline \multicolumn{5}{|c|}{ Model Summary } \\
\hline Model & $\mathbf{R}$ & R Square & Adjusted R Square & Std. Error of the Estimate \\
\hline 1 & $.325^{\text {a }}$ & .106 & .085 & 5.812 \\
\hline \multicolumn{6}{|c|}{ a. Predictors: (Constant), Promosi_Total, Lokasi_Total } \\
\hline
\end{tabular}

Sumber : Output SPSS yang telah di olah (2019).

Berdasarkan tabel diatas koefisien determinasi ( $\mathrm{R}$ square) yang diperoleh sebesar 0,106. Hal ini menunjukan bahwa sebesar 10,6\% keputusan pembelian sebagai variabel dependen dipengaruhi oleh lokasi

Artinya jika variable lokasi (X1) meningkat satu-satuan dengan asumsi bahwa variable promosi (X2) tetap, maka keputusan pembelian akan meningkat sebesar 0,200.

c. Variabel promosi (X2) berpengaruh positif terhadap keputusan pembelian (Y) dengan nilai koefisien sebesar 0,204. Artinya jika variable promosi (X2) meningkat satu-satuan dengan asumsi bahwa variable lokasi (X1) tetap, maka keputusan pembelian akan meningkat sebesar 0,204. dan promosi sebagai variabel independen dan sisanya sebesar 89,4 \% dipengaruhi oleh faktor-faktor lain diluar model penelitian ini.

Tabel 3. Hasil Uji Parsial Lokasi (X1) Terhadap Keputusan pembelian (Y)

\begin{tabular}{|c|c|c|c|c|c|c|}
\hline \multicolumn{7}{|c|}{ Coefficients } \\
\hline \multirow{2}{*}{\multicolumn{2}{|c|}{ Model }} & \multicolumn{2}{|c|}{$\begin{array}{l}\text { Unstandardized } \\
\text { Coefficients }\end{array}$} & \multirow{3}{*}{$\begin{array}{c}\begin{array}{c}\text { Standardized } \\
\text { Coefficients }\end{array} \\
\text { Beta } \\
\end{array}$} & \multirow[t]{2}{*}{$\mathrm{t}$} & \multirow[t]{2}{*}{ Sig. } \\
\hline & & B & Std. Error & & & \\
\hline \multirow[t]{2}{*}{1} & (Constant) & 33.481 & 3.622 & & 9.243 & .000 \\
\hline & Lokasi_Total & .246 & .094 & .269 & 2.608 & .011 \\
\hline
\end{tabular}

Sumber : Output SPSS yang telah di olah (2019).

Dari tabel diatas nilai signifikansi

ebesar 0,011 dan nilai t hitung sebesar 2,608

lokasi terhadap keputusan pembelian sedangkan untuk $t$ tabel 1,988. Dengan menunjukkan nilai $\mathrm{t}$ hitung $>\mathrm{t}$ tabel $(2,608$ $>1,988)$ sejalan dengan sig < 0,05 $(0,011<$ demikian dari hasil uji parsial (uji t) antara $0,05)$ sehingga H0 ditolak dan Ha diterima, 
yang artinya "Terdapat pengaruh yang signifikan antara lokasi terhadap keputusan pembelian pada produk Manset Safety di
Toko Tawakkal Pondok Aren - Tangerang selatan".

Tabel 4. Hasil Uji Parsial Promosi (X2) Terhadap Keputusan pembelian (Y)

\begin{tabular}{|c|c|c|c|c|c|c|}
\hline \multicolumn{7}{|c|}{ Coefficients ${ }^{a}$} \\
\hline \multirow{2}{*}{\multicolumn{2}{|c|}{ Model }} & \multicolumn{2}{|c|}{ Unstandardized Coefficients } & \multirow{2}{*}{$\begin{array}{c}\text { Standardized Coefficients } \\
\text { Beta }\end{array}$} & \multirow[b]{2}{*}{$\mathbf{t}$} & \multirow[b]{2}{*}{ Sig. } \\
\hline & & $\mathrm{B}$ & Std. Error & & & \\
\hline \multirow[t]{2}{*}{1} & (Constant) & 30.785 & 5.077 & & 6.063 & .000 \\
\hline & Promosi_Total & .267 & .112 & .247 & 2.382 & .019 \\
\hline
\end{tabular}

Sumber : Output SPSS yang telah di olah (2019).

Dari tabel di atas nilai signifikansi sebesar 0,019 dan nilai $t$ hitung sebesar 2,382. Dengan demikian dari hasil uji parsial (uji $t$ ) antara promosi terhadap keputusan pembelian menunjukkan nilai $\mathrm{t}$ hitung $>\mathrm{t}$ tabel yaitu 2,382 $>1,988$ sejalan dengan sig

$<0,05(0,019<0,05)$ sehingga H0 ditolak dan Ha di terima yaitu "Terdapat pengaruh yang signifikan antara promosi terhadap keputusan pembelian pada produk Manset Safety di Toko Tawakkal Pondok Aren Tangerang selatan".

Tabel 5. Hasil Uji f (Simultan)

\begin{tabular}{|c|c|c|c|c|c|c|}
\hline \multicolumn{7}{|c|}{ ANOVA $^{a}$} \\
\hline \multicolumn{2}{|r|}{ Model } & Sum of Squares & df & Mean Square & $\mathrm{F}$ & Sig. \\
\hline \multirow[t]{3}{*}{1} & Regression & 343.590 & 2 & 171.795 & 5.085 & $.008^{\mathrm{b}}$ \\
\hline & Residual & 2905.354 & 86 & 33.783 & & \\
\hline & Total & 3248.944 & 88 & & & \\
\hline \multicolumn{7}{|c|}{ a. Dependent Variable: Keputusan_Pembelian_Total } \\
\hline \multicolumn{7}{|c|}{ b. Predictors: (Constant), Promosi_Total, Lokasi_Total } \\
\hline
\end{tabular}

Sumber : Output SPSS yang diolah (2019)

Dari hasil uji $f$ dapat diperoleh nilai $f$ hitung $>\mathrm{f}$ tabel yaitu 5,085> 3,11 dan nilai sig $<0,05(0,008<0,05)$ artinya dapat disimpulkan "Terdapat pengaruh signifikan lokasi dan promosi "secara simultan" terhadap keputusan pembelian pada produk Manset Safety di Toko Tawakkal Pondok Aren - Tangerang Selatan".

\section{Pembahasan}

1. Berdasarkan nilai rata- rata kuesioner dari variabel lokasi yaitu 3,42 yang berada pada interval $(3,40-4,19)$ dimana tanggapan responden terhadap variabel lokasi (X1) memiliki katagori baik.

2. Berdasarkan nilai rata- rata kuesioner dari variabel promosi yaitu 4,06 yang berada pada interval $(3,40-4,19)$ dimana tanggapan responden terhadap variabel promosi (X2) memiliki katagori baik.

3. Berdasarkan nilai rata- rata kuesioner dari variabel keputusan pembelian yaitu 3,50 yang berada pada interval $(3,40-$ $4,19)$ dimana tanggapan responden terhadap variabel keputusan pembelian
(Y) memiliki katagori skala baik.

\section{PENUTUP}

\section{SIMPULAN}

1. Lokasi memiliki pengaruh yang signifikan terhadap keputusan pembelian, dimana diperoleh nilai $t$ hitung $>\mathrm{t}$ table $(2,608<1,988)$ dan sig $<$ $0,05(0,011<0,05)$, dengan demikian $\mathrm{H} 0$ ditolak dan $\mathrm{Ha}$ diterima yang artinya terdapat pengaruh yang signifikan antara lokasi terhadap keputusan pembelian.

2. Promosi memiliki pengaruh yang signifikan terhadap keputusan pembelian, dimana diperoleh nilai $t$ hitung $>\mathrm{t}$ table $(2,382<1,988)$ dan sig $<$ $0,05(0,019>0,05)$, Dengan demikian $\mathrm{H} 0$ ditolak dan $\mathrm{Ha}$ diterima yang artinya terdapat pengaruh yang signifikan antara promosi terhadap keputusan pembelian.

3. Lokasi dan promosi memiliki pengaruh yang signifikan secara silmultan terhadap keputusan pembelian, dimana diperoleh nilai $\mathrm{f}$ hitung $>\mathrm{f}$ table $(5,085<$ 
3,11) dan sig >0,05 $(0,008>0,05)$, Dengan demikian $\mathrm{H} 0$ ditolak dan $\mathrm{Ha}$ diterima yang artinya tidak terdapat pengaruh yang signifikan secara "Silmultan" antara lokasi dan promosi terhadap keputusan pembelian

\section{Saran}

1. Berdasarkan pernyataan "Tempat parkir Toko Tawakkal di pondok aren sangat luas" mendapatkan skor terendah 2,63. Disarankan pemilik Toko Tawakal meningkatkan pelayanan dari segi lokasi terutama dari sarana tempat parkir, sehingga pelanggan merasa nyaman dan tidak binggung memarkirkan kendaraannya saat akan membeli produk dari Toko Tawakkal.

2. Pada pernyataan "Saya pernah ditawarkan produk Manset Safety dijalan", di mana diperoleh skor terendah 3,19. Diharapkan pemilik toko meningkatkan kembali promosi melalui penjualan langsung, dengan diskon yang menarik.

3. Pada pernyataan "Saya membeli produk Manset Safety direkomendasikan oleh kerabat", dimana diperoleh skor 3,18. disimpulkan bahwa masih kurangnya minat dari pelanggan untuk merekomendasikan produk Toko Tawakkal kepada kerabat. Oleh karna itu harapan agar Toko Tawakkal lebih mengarahkan tim pemasarannya untuk mengarahkan konsumen merekomendasikan produk Manset Safety kepada kerabatnya.

\section{DAFTAR PUSTAKA}

Alma, Buchari. (2011). Manajemen Pemasaran Dan Pemasaran Jasa. Bandung: Alfabeta.

Choliq, Abdul. (2013). Pengantar Manajemen., Semarang: Raffi Sarana Perkasa.

Ghozali, Imam. (2013). Aplikasi Analisis Mulyivariate Dengan Program IBM SPSS 19 (Edisi ke 5). Semarang: Badan Penerbit Universitas diponogoro.
Haizer, Jay \& Barry Render. (2015). Manajemen Operasi (edisi ke- 7). Jakarta: Salemba Empat.

Kotler, Philip, Amstrong Gary. (2013). Prinsip- prisip Pemasaran, edisi ke 13 Jilid 1 Jakarta: Erlangga.

Haryadi, R. N., Anda Rojali, Khumidin, \& M. Fauzan. (2021). Sosialisasi Penggunaan Online Shop berbasis Website di UMKM Cimanggis. Jurnal Pengabdian Bina Mandiri, 1(1), 10-16. https://doi.org/10.51805/jpmm.v1i1 .3

Lupiyoadi, Rambat. (2013). Manajemen Pemasaran Jasa. Jakarta: Salemba Empat.

Nurjaya, N., et al (2021). Pengaruh Brand Image Terhadap Keputusan Pembelian Pada PT. Wahana Motor Di Wilayah Cianjur. Jurnal Ilmiah PERKUSI, 1(2), 291-296.

Suparyanto \& Rosad. (2015). Manajemen Pemasaran ., Bogor: IN MEDIA.

S.P, Hasibuan Malayu. (2013). Manajemen Sumber Daya Manusia. Jakarta: PT Bumi Aksara.

Tjiptono, Fandy. (2015). Strategi Pemasaran (edisi 4). Yogyakarta: ANDI.

Rakhman, Arief. (2018). Strategi Marketing. Jakarta: Gramedia Pustaka.

Sugiyono. (2016). Metode Penelitian Kualitatif dan Kuantitatif \& RND. Bandung: Alfabeta. 